\title{
Building major competencies for enhancing higher education for sustainable development
}

\author{
Alexander Ivanov $^{1}{ }^{*}$, Svetlana Tolstikova ${ }^{1}$, Larisa Ovcharenko ${ }^{1}$, and Tatiana Morozova ${ }^{1}$ \\ ${ }^{1}$ Department of General and Practical Psychology, Moscow City University, 4 Vtoroy \\ Selskohoziajstvenny proezd, Moscow, 129226, Russian Federation
}

\begin{abstract}
This paper focuses on the specifics and preconditions for building major competencies that are envisaged for enhancing higher education for sustainable development (ESD). It looks into the professional development of specialists in higher education, factors affecting individual stages of professional development of these specialists, as well as into the role of the environment in their professional development. Furthermore, it studies the formal and informal learning as the important setting leading to the creation of the major competencies for linking globalization, complexity and environmental responsibility and channelling them to students through the teaching process in higher education.
\end{abstract}

\section{Introduction}

Higher education institutions (HEI) assign key competences for sustainable development that enable professionals to cope with the challenges in different socio-economic environments. Universities are becoming increasingly competent - based on the development of skilled workers who must be able to face the demands of organisational competition and the labour market [1-3]. Therefore, universities integrate their curricula with a wide range of skills, such as knowledge, skills and skills, as well as skills in the field of sustainable development.

This educational movement is supported by the need to rethink the purpose of education and to change the curriculum and educational practices. Universities are making important changes to their programmes to boost students' professional skills, while others are planning to improve their programme's learning outcomes. This underlines the significant progress and potential of education for sustainable development (ESD), although more efforts will be needed to move towards a sustainable future. Higher education institutions play a crucial role in implementing and promoting sustainable development initiatives $[4,5]$. One of the key questions to be answered is whether university leaders, lecturers and students are doing a good job in implementing sustainable development in higher education in their institutions. This reinforces the need to strengthen education at all levels, build on the success of the ESD and translate it into political and institutional contexts $[6,7]$.

According to a United Nations report, justice means understanding a student's learning needs in order to reduce the barriers to his or her academic success. With increasing demands

\footnotetext{
*Corresponding author: aivanov7@rambler.ru
} 
on society and the environment due to increasing urbanization, migration and human migration, it is clear that global action is needed to build a more sustainable future [8]. Building a sustainable future means more than just creating green campuses and implementing recycling efforts and initiatives for global civic engagement.

In recent years, the concept of education and sustainable development has become a central educational initiative, helping to address many of the problems associated with human development. Given the importance of higher education for the development of a more sustainable future, it can serve as a powerful tool for creating this education, according to a new study. As the world becomes more globalised and interdependent, the role of higher education in building a sustainable future has become more important. There is increasing interest in contributing to the United Nations Sustainable Development Goals by educating pupils about the importance of sustainable development and its role in human development. This the way how leading higher education institutions can contribute to the necessary societal change beyond their classrooms $[9,10]$.

There is a theory of economic growth, stressing that higher education was an important factor in improving the regional economy and human capital. This theory confirms the positive role of education in the development of sustainable economy.

\section{Teaching environmental responsibility in higher education}

Given the increasing demands on society and the environment resulting from increasing urbanization, increasing human migration, and increasing energy demand, it is clear that global action is needed to create a more sustainable future. In recent years, the concept of education and sustainable development has become a central educational initiative, helping to address many of the problems associated with human development [11]. As the world becomes increasingly globalized and interdependent, efforts to build a sustainable future will become more important. Given the importance of higher education for the development of a more sustainable world, it can serve as a powerful means of creating this education. What inspires us to inspire environmentally-oriented higher education courses are the need to understand the development of sustainable environmental literacy.

By promoting environmental knowledge, dispositions, skills and behaviour relevant to the sustainability of the environment and human health and well-being, especially designed courses can improve students' ability to influence changes in higher education and promote a better understanding of environmental issues and their impact on human development [12]. Future research will be necessary for any study aiming at developing a significant new understanding of the impact of environmental issues and issues in their application to education in general and their role in environmental education. In particular, we could focus on the interaction between different aspects of environmental competence [13]. This information will allow a better understanding of the efforts and results of higher education in terms of environmental literacy, as well as specific measures to assess the impact of education on students' ability to influence changes in education in general and environmental issues in particular.

In general, measuring changes in environmental literacy in the context of developing a sustainable environmental education system has two advantages. First, we need to measure where environmental education is located in the sustainability movement at university locations. Second, it seeks to identify the role environmental education could play in promoting the necessary movement outside the classroom [14]. The specific aim is to educate students about the need for sustainable development by integrating sustainable development issues into all aspects of teaching, research and services. Research has shown that academics are particularly interested in filling their curriculum with sustainability concepts. This means reorienting the education system to help people think and act in ways that promote a more 
sustainable planet. In practice, this means equipping students with the knowledge, skills, attitudes and values needed to build a sustainable future [15]. Colleges and universities must produce students who are capable of dealing responsibly with the environment. To this end, students should develop a value system that emphasizes responsibility for themselves, others and the planet, conducts authentic interdisciplinary learning activities, and cultivates critical and creative thinking skills. The urgency that fuels this response suggests that higher education must continue to take a holistic approach to environmental education, not just one - outside the classroom [16]. By promoting the skills necessary to cultivate the knowledge, skills, attitudes and values necessary to create a sustainable future for our planet, our children and grandchildren, and the future of the world, it will be ready to provoke and sustain the necessary environmental responses.

Thence, higher education must help to develop and promote the ability of students to promote environmental improvement measures. Higher education institutions play a crucial role in implementing and promoting sustainable development initiatives. One of the most important questions to be answered is what university leaders, faculty and students should do to implement sustainable development. Justice means understanding students' learning needs while reducing the barriers to academic success. Building a sustainable future means more than just creating green campuses and implementing recycling efforts and global citizens' initiatives [17]. Areas of great opportunity include expanding formal environmental education and aligning students, faculty and staff with environmental programs and goals on campus. Together, these institutions are perhaps the most responsible for educating science students on environmental issues, staffing and implementing recycling programs, and establishing sustainable development initiatives such as green spaces.

One of the most encouraging findings is that there is strong support for greening and management systems at institutions of all types and sizes, including public and private colleges and universities, as well as private universities. While there are signs that colleges or universities are working to teach students about environmental issues, trends in higher education curricula are relatively weak compared to those in "greening" and "farm management" systems. Across regions and countries, there is work being done to teach and demonstrate sustainability as a practice. In fact, many universities worldwide offer programs large or small in environmental studies, and these programs promote students' interest in sustainability and environmental issues such as environmental protection and management systems. But only a small share of universities requires all students on campus to take environmental studies courses, regardless of their focus. Even if they are studying biology or environmental sciences, students at many institutions can complete their studies without acquiring basic environmental knowledge. Clearly, this is a problem that needs to be solved in the nearest future.

\section{Role of the environment and climate change in education}

There is no doubt that climate change has consequences for the earth and human life, and many students want to play an active role in combating it, but are not sure how to do so in the classroom [18]. Although the majority of scientists worldwide believe that climate change is occurring and man-made, there are no government standards requiring schools to teach it in social sciences, and educators have the ability to incorporate elements of it into students' lessons to ensure that students have all the knowledge they need to address the problem in any capacity that is their own. Universities should help students in their efforts to take an active role in learning about climate change and perhaps address it as an issue in the future. Climate change is no longer just of interest to scientists, but also to educators [19]. Teaching in social studies remains in the hands of individual teachers and is decided by individual school districts. As students learn about climate change in science classes, they will be able 
to make informed decisions about policy institutions that are responsible for policies that affect greenhouse gas emissions. Teachers say they need improved curricula and policies, and a recent finding demonstrate that teachers feel they have the knowledge and skills to teach climate change. Students have to learn and talk about climate change to develop critical thinking skills, solve problems, and work with others to find solutions to the complex challenges of today and the future. Almost half of students are aware that climate change is man-made, but do not believe that human action and mitigation will be effective. The new revision of science standards emphasizes climate change, offers some advice to science teachers, and encourages them to include the topic in the curriculum. The use of science as an appropriate educational context in which to discuss global warming and climate change should be adequately supported [20].

Institutions of higher education need to engage in a discussion on how to teach the climate in a way that does not contradict the scientific consensus on the causes and effects of global warming and the role of human activities. Important climate-related scientific concepts are already being incorporated in primary school, but climate change is explicitly addressed only in middle school. Many of the committee members felt that they needed to answer questions about the effects of climate change and the eco-fears that it causes in younger students, and that this was not an issue that could only be addressed by science teachers. Environmental principles and concepts should be a part of the strategy which provides guidelines for teachers to implement new scientific standards. Some schools, however, still struggle to include these studies in their curriculum. Public schools need to educate young people about current and future environmental challenges, and create a group of environmental leaders that will achieve that goal [21]. A scholarship program can be established to support climate change education programs for young people and provide teachers with training and professional development related to improving climate literacy among students [22].

\section{Formal and informal learning in sustainable higher education}

Formal learning should be structured and give pupils, teachers and institutions the opportunity to ensure that learning objectives are achieved. Informal learning, on the other hand, takes place and continues to take place in the absence of formal learning, which is highly structured and institutionally promoted and takes place outside the traditional classroom, such as in a classroom or informal environment [23, 24]. A quick look at the typology shows that formal learning involves an educational process whose primary task is the creation of new knowledge. Learning is described by various classifications that are linked to the environment and circumstances in which learning is most likely. Specific pedagogy and materials that facilitate the educational process are generally provided in a formal learning context. A non-formal learning environment is found where the primary mission is not necessarily education. Learning that takes place in a specific learning environment the result of an activity of interest to an individual or group and cannot be recognised as learning in the traditional sense of the word (e.g. formal or informal). Learning that is planned and structured as a series of short courses organized in response to identified interests and needs. Learning that is not formally organized by the employer into a program or curriculum. Learning that takes place in a work context that relates to an activity of interest to the individual or group (e.g. vocational training, on-the-job training, etc.) [25]. Informal education is closely linked to informal learning, which takes place in relationships between members of society. It can be seen that different parties are involved and it may or may not be explicitly promoted. Informal education is created when concepts are adapted to the individual needs of each student [26]. What students learn in higher education is a function of both formal and informal experience. Formal learning takes place in the classroom and related activities structured by teachers and others to help students achieve certain cognitive 
and other goals. Informal learning includes a wide range of activities such as lectures, quizzes, workshops and other forms of learning. The basic argument here is the obvious point to make, that much of our learning takes place outside the formal confines of the classroom. One reason is that learning cannot be replaced by education, as we see in lifelong learning. Learning is a process that takes place all the time and requires intention and commitment [27, 28]. The focus on learning is important, but if it is all we think about and what we do, we are doing everyone a disservice.

While universities have historically been characterized by the emphasis on traditional teaching methods required in the classroom, the future of universities is determined by the response of universities to informal learning. Since informal learning and formal learning overlap, it is not easy to separate purely student social activities from those related to learning, as they often take place outside the traditional classroom. The balance between formal and informal frameworks must change to demand greater autonomy from students and to better support them in their learning.

This has been around for several years, but traditionally it has placed a high value on formal learning processes over informal learning as it is learned in the workplace. Moreover, anthropologists have found that complex learning can take place in indigenous communities that do not have formal educational institutions, as in the case of indigenous peoples in South America and Africa. Non-formal learning includes some of the same aspects of formal learning, but typically manifests itself as short-term, voluntary programs outside the framework of traditional educational institutions [29]. The need for this category is evident in programmes designed to learn outside the framework of educational institutions. However, since learners participate in these programmes in an educational environment, researchers have considered them formalising in order to be involved in the area of informal learning. Common ground between the two often includes the need for students to follow a planned curriculum and to use formal and non-formal learning methods.

\section{Professional development of specialists in higher education}

Specialists may have a variety of educational qualifications, but most have behaved well and require relevant professional experience. Some education and development specialists need a Bachelor's degree, others a training, and most do not need one. Others may have behaved well and need work experience, but most do not, and some may behave well but not well enough for the job [30]. Many positions require work experience, and employers may prefer to hire employees from companies that work in the industry or use technology-based tools.

Consultancy and employment management firms are hiring more specialists to train and develop their staff, as more companies seek to hire them to cut costs and cope with the high costs of recruiting and training staff in higher education. Many employers prefer a Master's degree because most apprenticeship or development jobs require a Bachelor's degree and a degree can offer a competitive advantage $[31,32]$. If a company wants to recruit and retain the best people for a particular field, it can rely on the expertise of a graduate program in the professional development of specialists in higher education. Graduates with the certification will find good employment opportunities, and those with a Master's degree in the professional development of higher education specialists will do even better. Business cycles and economic conditions influence the demand for employees in the education and training of skilled workers.

Nowadays, the number of disciplines in higher education and the degree of professional development of skilled workers vary according to the area of responsibility. Graduates who obtain certificates will enjoy the best opportunities for advancement. Interpersonal skills must be imbued with skills such as communication, interpersonal skills, communication 
skills and communication skills. Over the next decade, above-average growth in employment opportunities is expected [33].

Employment in the training and development of skilled workers is expected to increase as companies develop new media and technologies and introduce them into their training programmes. Workers in many professions will have to attend training and qualification courses throughout their careers, creating a demand for worker-led training activities [34]. For example, organizations are increasingly using video, audio, video and other forms of higher education and online courses in their training programs. In addition to the available certification programs, there are many online courses that can help with personal and professional development [35]. To lead effective communication and faster progress there are courses that help learners achieve excellence in their careers. These include courses entitled around the lines like "Becoming a Successful Leader" and "Leading Effective Communication," as well as a number of other courses run by leading non-profit organizations. For specific expertise required in the financial world, professional training courses, including courses in finance, accounting, financial management and financial planning, as well as a range of other courses are offered. In general, the professional development of specialists in higher education nowadays is a serious and complex process that requires lots of time and effort.

\section{Conclusions}

Overall, it becomes clear that we need to offer teachers and young people fair access to rich, relevant learning and develop leadership capacity at all levels. Modern universities are forging links with industry to establish research laboratories and scientific centres. Competitive higher education depends on the development of a strong relationship between universities and industry and the integration of research and education. For more students and more institutions to benefit, universities, research institutions and other institutions need to take sustainability issues and challenges more into account and allocate resources. Universities develop a long-term commitment to the sustainability of their research, education and research institutions. Senior administrators at universities and colleges who are leaders in sustainability could help inform and train key government agencies and policymakers. Higher education is facing rising costs and challenges such as climate change and the effects of global warming. If one says that an educational institution committed to building a sustainable and humane future and wanting to learn to build it would be an exciting and challenging place, he or he should place it in the context of a competitive higher education environment.

The Sustainable Development Goals clearly show that higher education is part of these goals, as it is part of high-quality education and can offer opportunities for lifelong learning. Furthermore, universities can help to promote human sustainability, and therefore the need for them to develop a sustainable perspective is the main focus. Specifically, SDG Goal 4.3 aims to promote equal access to higher education regardless of gender and socio-economic status. This can be reflected in the SDG's Goal 4.7, which aims to equip learners with the knowledge and skills for sustainable development. Specifically, the United Nations proposes to foster the development of higher education as a key component of the sustainable development goals. All of these makes it very relevant to invest into boosting the major competencies for enhancing higher education for sustainable development. 


\section{References}

1. E. Abad-Segura, M.D. González-Zamar, Journal of Cleaner Production, 294, 126133 (2021)

2. E. Fleacă, B. Fleacă, S. Maiduc, Sustainability, 10(4), 1032 (2018)

3. F. Findler, N. Schönherr, R. Lozano, D. Reider, A. Martinuzzi, International Journal of Sustainability in Higher Education, 20(1), 23-38 (2019)

4. A.V. Agbedahin, Sustainable Development, 27(4), 669-680 (2019)

5. M. Singer-Brodowski, A. Brock, N. Etzkorn, I. Otte, Environmental education research, 25(4), 492-507 (2019)

6. J.H.P.P. Eustachio, A.C.F. Caldana, M. Will, A.L. Salvia, I.S. Rampasso, R. Anholon, M. Kovaleva, Sustainability, 12(9), 3761 (2020)

7. W. Leal Filho, M. Will, A.L. Salvia, M. Adomssent, A. Grahl, F. Spira, Journal of Cleaner Production, 232, 1394-1401 (2019)

8. E. Boeren, International Review of Education, 65(2), 277-294 (2019)

9. V. Grebennikova, T. Bonkalo, N. Nikitina, Z. Gardanova, O. Grebennikov, Espacios, 40(44), 25 (2019)

10. J. Mensah, S.R. Casadevall, Cogent Social Sciences, 5(1), 1653531

11. J. O'Flaherty, M. Liddy, Environmental Education Research, 24(7), 1031-1049 (2018)

12. J. Tai, R. Ajjawi, D. Boud, P. Dawson, E. Panadero, Higher Education, 76(3), 467-481 (2018)

13. I. Molderez, E. Fonseca, Journal of Cleaner Production, 172, 4397-4410 (2018)

14. C.R. Clark, J.E. Heimlich, N.M. Ardoin, J. Braus, Environmental Education Research, 26(3), 381-399 (2020)

15. N. Nikitina, E. Romanova, E. Komarova, S. Tolstikova, V. Grebennikova, Review of European Studies, 7(3), 66-79 (2015)

16. C. Marouli, Sustainability, 13(5), 2901 (2021)

17. S. Yáñez, Á. Uruburu, A. Moreno, J. Lumbreras, Journal of Cleaner Production, 207, 57-66 (2019)

18. S.R. Stapleton, Environmental Education Research, 25(5), 732-750 (2019)

19. C.A. Jones, A. Davison, Geoforum, 118, 190-200 (2021)

20. M.C. Monroe, R.R. Plate, A. Oxarart, A. Bowers, W.A. Chaves, Environmental Education Research, 25(6), 791-812 (2019)

21. M.A. Windschitl, D. Stroupe, Journal of Teacher Education, 68(3), 251-261 (2017)

22. K.C. Busch, J.A. Henderson, K.T. Stevenson, Environmental Education Research, 25(6), 955-971 (2019)

23. L. Janssens, K. Smet, P. Onghena, E. Kyndt, International Journal of Training and Development, 21(2), 92-112 (2017)

24. A.A. Holland, Computers \& Education, 128, 214-226 (2019)

25. A. Lantz-Andersson, M. Lundin, N. Selwyn, Teaching and Teacher Education, 75, 302$315(2018)$

26. S. Colognesi, C. Van Nieuwenhoven, S. Beausaert, European Journal of Teacher Education, 43(2), 258-276 (2020)

27. P. Jarvis, Adult education and lifelong learning: Theory and practice (2004)

28. M.L. Bernacki, J.A. Greene, H. Crompton, Contemporary Educational Psychology, 60, 101827 (2020)

29. N. Denzin, Y. Lincoln, L. Smith (eds.), Handbook of critical and indigenous methodologies (2008)

30. G.M. Alam, A.R. Forhad, I.A. Ismail, Technological Forecasting and Social Change, 159, $120184(2020)$ 
31. D.O. Jewell, S.F. Jewell, B.E. Kaufman, Human Resource Management Review, 100749 (2020)

32. S. Wilkins, S. Neri, Journal of Studies in International Education, 23(4), 451-472 (2019)

33. E. Smith, P. White, Journal of Science Education and Technology, 28(1), 26-40 (2019)

34. H. Schroth, California Management Review, 61(3), 5-18 (2019)

35. A. Stathopoulou, N.T. Siamagka, G. Christodoulides, European Management Journal, 37(4), 421-431 (2019) 